Acta Theriologica 40 (2): 197-217, 1995.

PL ISSN 0001-7051

\title{
The roles of predation, snow cover, acorn crop, and man-related factors on ungulate mortality in Białowieża Primeval Forest, Poland
}

\author{
Henryk OKARMA, Bogumiła JĘDRZEJEWSKA, Włodzimierz JĘDRZEJEWSKI,
} Zbigniew A. KRASIŃSKI and Lech MIŁKOWSKI

\begin{abstract}
Okarma H., Jędrzejewska B., Jędrzejewski W., Krasiński Z. A. and Miłkowski L. 1995. The roles of predation, snow cover, acorn crop, and man-related factors on ungulate mortality in Białowieża Primeval Forest, Poland. Acta Theriologica 40: 197-217.
\end{abstract}

The relative importance of various mortality factors was studied in populations of European bison Bison bonasus, moose Alces alces, red deer Cervus elaphus, roe deer Capreolus capreolus, and wild boar Sus scrofa in the exploited and protected parts of Białowieża Primeval Forest, eastern Poland. Data consisted of harvest quotas and records of ungulate carcasses found to have died from poaching, gun-wounds, traffic accidents, disease/starvation, and killed by wolves Canis lupus, lynx Lynx lynx and stray dogs. In the exploited forests, red deer suffered most from wolf predation (cause of death in $58 \%$ of deer carcasses found) and disease/starvation (22\%). Important factors of roe deer mortality were disease/starvation (31\% of carcasses), lynx (28\%), and wolves $(23 \%)$. European bison and moose died mainly from disease ( $79 \%$ and $52 \%$, respectively), and poaching ( $14 \%$ and $32 \%$, respectively). Wild boar suffered mostly from diseasel /starvation $(61 \%)$ and wolf predation $(16 \%)$. Hunters, poachers, and traffic accidents acted non-selectively on the 5 ungulate species and on the sex and age classes. Wolves positively selected red deer and took fewer wild boar than expected at random. Lynx specialised on roe deer, and stray dogs killed wild boar more often than expected. Lynx strongly selected red deer calves. Stray dogs killed more juvenile roe deer than expected. In wild boar, mortality from starvation/disease increased in the year following an abundant acorn crop. Heavy acorn crop led to an increase in the numbers of wild boar, many of which died the following year. In the other ungulates, variation in acorn crop had no effect on death from starvation and disease. Variation in snow cover did not affect ungulate mortality in mild and moderate winters, but the extremely severe winter of $1969 / 70$ (snow depth up to $100 \mathrm{~cm}$ ) caused mass deaths of red deer, roe deer and wild boar.

Key words: mortality, climatic conditions, Cervidae, Bison bonasus, Canis lupus, Lynx lynx, Sus scrofa

Mammal Research Institute, Polish Academy of Sciences, 17-230 Białowieża, Poland (HO, WJ); Workshop for Ecology and Protection of the Natural Environment, P.O. Box 23, 17-230 Białowieża, Poland (BJ); Białowieża National Park, 17-230 Białowieża, Poland (ZAK); Białowieża Forest Administration, 17-230 Białowieża, Poland (LM)

\section{Introduction}

Ungulates in central Europe have long experienced man-caused mortality in addition to natural causes such as predation and disease. In the last millenium, 
man's activity became the most important factor shaping the dynamics of ungulates through the extermination of some species (eg the auroch Bos primigenius Bojanus, 1827), spatial and numerical restriction of large predators and the destruction of forests, the prime habitat of European native ungulates. In the 19th century, "modern" game management introduced a wide-scale manipulation of ungulate populations which, in many European countries, became almost animal husbandry. Therefore, attempts to investigate the natural functioning of ungulate populations in Europe are rarely possible.

In this respect, Białowieża Primeval Forest, located on the Polish-Belarussian border, is an unique area in the temperate zone of lowland Europe. The large and relatively well preserved forests harbour five species of ungulates: European bison Bison bonasus Linnaeus, 1758, moose Alces alces Linnaeus, 1758, red deer Cervus elaphus Linnaeus, 1758 , roe deer Capreolus capreolus Linnaeus, 1758, and wild boar Sus scrofa Linnaeus, 1758, and two species of large predators: wolf Canis lupus Linnaeus, 1758 and lynx Lynx lynx Linnaeus, 1758.

In this paper, we analyse the differential effects of different mortality factors on species, and their age/sex classes. The following sources of mortality were analysed: (1) hunting harvest, (2) gun-wounds, (3) poaching, (4) traffic accidents, (5) predation by wolf, (6) predation by lynx, (7) predation by stray dogs, and (8) starvation and disease. The influence of winter conditions (snow depth) and acorn crop on ungulate survival was also investigated.

\section{Study area}

Białowieża Primeval Forest (BPF, $1250 \mathrm{~km}^{2}$ ) is one of the best preserved forest ecosystems in lowland temperate Europe (Faliński 1986). The forest is divided into two parts by the Polish-Belarussian border. The Polish part $\left(580 \mathrm{~km}^{2}\right)$, where the study was conducted, has been exploited for timber since 1915, except for an area of $47.5 \mathrm{~km}^{2}$, which is strictly protected as the Białowieża National Park (BNP). Most of the tree stands in the exploited part of the forest are dominated by Norway spruce Picea abies and Scots pine Pinus silvestris (54\% of the area). These species have been replanted for commercial timber. Tree stands dominated by oak Quercus robur and hornbeam Carpinus betulus cover $13 \%$ of the area, birch (Betula verrucosa and B. pubescens) and aspen Populus tremula $13 \%$, alder Alnus glutinosa $17 \%$, and ash Fraxinus excelsior 3\%. Other deciduous tree species, eg Norway maple Acer platanoides and lime Tilia cordata almost disappeared from the exploited part of the Forest as a result of management. The majority of the exploited forests are stands of secondary origin (ie planted). The average age of tree stands is 72 years. The oldest age classes ( $>100$ years) form $30 \%$, and the youngest ( $<40$ years) $27 \%$ of all stands (Jędrzejewska et al. 1994).

The Białowieża National Park preserves natural forests dominated by oak (20\% of area) and hornbeam (19\%). Pine forests cover $11 \%$ and spruce $16 \%$ of area, lime and maple $9 \%$, alder $12 \%$ of area, ash $6 \%$, and birch and aspen $7 \%$. The average age of tree stands is 130 years. Regeneration takes place under the canopy of old stands. Neither exploitation of timber and game, nor motor transportation is allowed in BNP.

In the exploited part of BPF (divided into 9 hunting districts), all ungulates except European bison are hunted under an annual harvest plan. European bison are a protected species and are excluded from regular game management; the free-living population is managed by the National Park authority. In BNP, no hunting of any animals is permitted. Wolf and lynx have been protected in the 
entire Polish part of BPF since 1989. Wolves are intensively hunted in the Belarussian part of BPF. In 1981, a 3-m high wire fence was built by the Soviets along their state border. Since that time, movement of ungulates between Polish and Belarussian parts of BPF has no longer been possible. Wolves and lynx, however, do cross the border by climbing or digging under the fence.

The climate of Białowieża is transitional, but continental features prevail (Olszewski 1968). During the 12 years of the study $(1969 / 70,1977 / 78$, and 1984/85 to 1993/94), both extremely severe winters and unusually warm ones were recorded (Fig. 1).

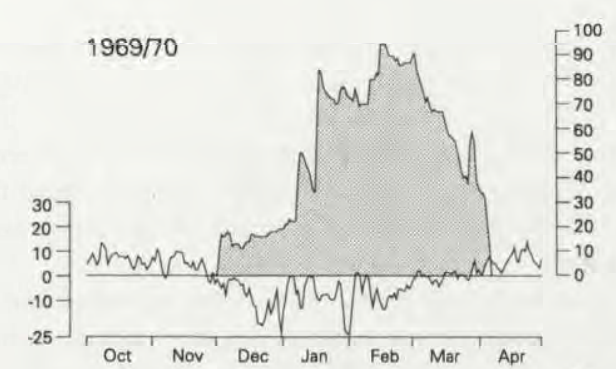

$1977 / 78$

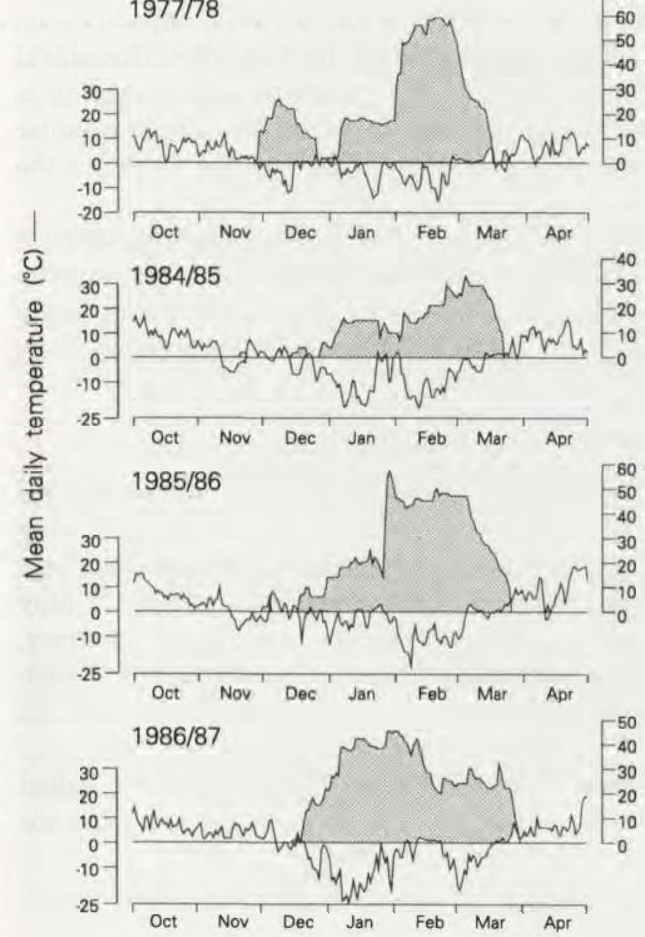

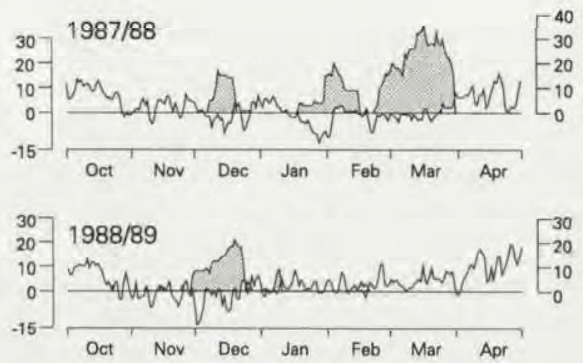
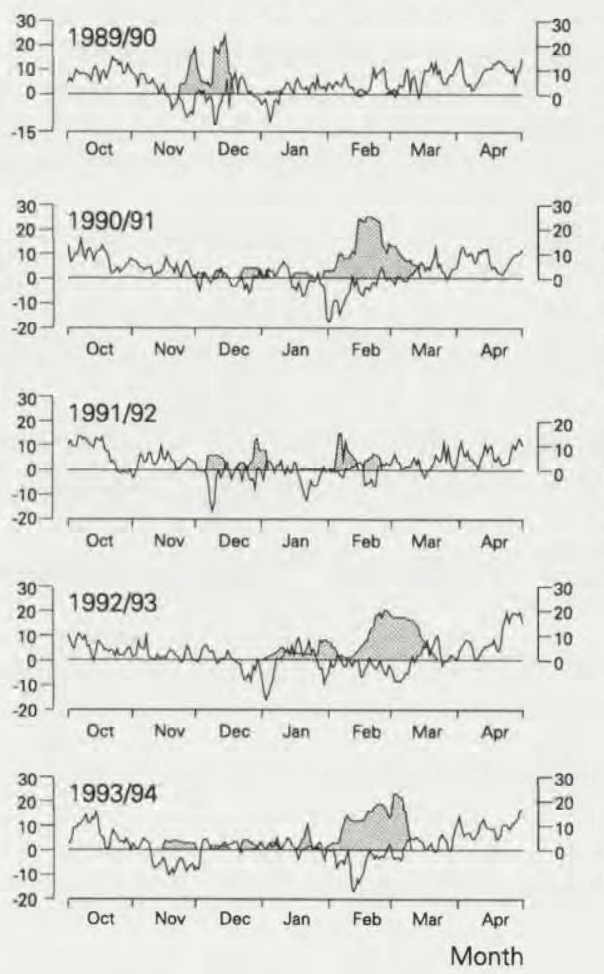

Fig. 1. Mean daily temperature and snow cover during 12 winter seasons (1969/70, 1977/78, 1984/85-1993/94) in Białowieża Primeval Forest. 


\section{Material and methods}

\section{Estimation of ungulate and large predator numbers}

Since the late $1960 \mathrm{~s}$, for 6 years in the exploited forests of BPF and 2 years in BNP, drive censuses of ungulates were made (see Pucek et al. 1975 and Jędrzejewska et al. 1994 for details). In the exploited forests, drive censuses were conducted on randomly chosen forest compartments that covered from 29 to $55 \mathrm{~km}^{2}$ (ie from 5 to $13 \%$ of the entire area of exploited forest). In BNP, drive censuses were made in two blocks of compartments covering $11.2 \mathrm{~km}^{2}$ (24\% of BNP area).

Each area to be counted (one compartment or block of adjoining compartments) was surrounded by observers placed at intervals of 50-100 m (to keep visual contact). Observers along three sides of the area remained stationary, while those along the fourth side moved inward through the entire area. Each of the observers moving in a "battue" line kept visual contact with neighbours. The observers (both stationary and moving ones) recorded ungulates passing through a line of observers (on their right hand side only) out and into the closed area being censused. Such censuses yielded the minimum numbers of ungulates calculated as the difference between the number of ungulates seen to leave censused area and those observed going into it.

Sex and age of ungulates (as juveniles $<1 \mathrm{yr}$, adult female, or adult male) were recorded during winter driving censuses, year-round observations and counts at feeding sites by game wardens and (in the case of European bison) the staff of BNP. Numbers of European bison were independently estimated by the staff of BNP. Bison are counted each year in January or February, depending on weather conditions, when they congregate around winter supplementary feeding sites (Krasiński 1978). Since some individuals (mainly adult bulls) do not come to feeding places, snow-tracking is conducted several times during winter after new snow-fall to estimate their number. Winter fodder (hay, browse, beet) is supplied in several feeding racks for ungulates (especially for bison) in the exploited forests of BPF, but not in BNP.

Wolves and lynx were censused by counting tracks in snow by game wardens in 9 hunting districts in the exploited forests of BPF. Although attempts were made to differentiate various packs or pairs of wolves (by numbers in a pack, trail direction and visual estimate of track size) and various family groups of lynxes (mother and kittens) or solitary lynx, the numbers are indices of abundance only, and not absolute densities. The numbers of stray dogs were not censused.

\section{Harvest quotas}

The hunting season for game is regulated by the Ministry of Environment Protection, Natural Resources and Forestry (MEPNRF). During the study, ungulates were hunted during the following periods: male moose 1 September - 31 December, females and calves 1 October -31 December; male and calf red deer 21 August - 28 February, females 1 September - 31 January; male roe deer 11 May - 30 September, females and calves 1 October - 31 January; female wild boar 1 August - 31 January, males and young year round. Harvest quotas for a given season were summed to 31 March of each hunting season. Most of harvest was done by professional game wardens. For example, in the 1991/92 hunting season, game wardens harvested $36 \%$ all killed ungulates, amateur Polish hunters $32 \%$, staff of the local forestry administration $19.5 \%$, and amateur foreign hunters $12.5 \%$. Bison are culled annually to keep their numbers stable. Culling by the staff of BNP takes place in winter in a presence of a commision nominated by the MEPNRF.

\section{Registration of ungulate carcasses}

Carcasses from the exploited forests of BPF were registered during winter seasons by game wardens. Also, carcasses found by forest workers were reported to the game wardens who were obliged to examine them. Cause of death was determined whenever possible. Since most carcasses were found in the cold seasons, signs and tracks on snow helped to identify the cause of death. In cases when no signs of predator, accident, poaching etc were found, the carcass was classified as 'unknown cause of 
death'. In most of such cases, the animal had died from starvation, inanition, or disease so all 'cause unknown' deaths were treated as 'starvation/disease'. Registration of moose, red and roe deer and wild boar carcasses was done in $1969 / 70$ and $1977 / 78$ as pilot projects stimulated by unusually severe winters (Fig. 1). Since 1984, the registration has been conducted every year.

Survey of bison mortality has been done continually since bison reintroduction to the wild in 1952 by the staff of BNP and registered in calendar years. In this paper, only the data for 1969, 1977 and 1984-1993 are presented to make them compatible with information on other ungulates.

In the Białowieża National Park, searches for carcasses were made in 1986/87-1992/93 by the staff of the Mammal Research Institute PAS as a part of the long-term project on predator-prey relationships (see Jędrzejewski et al. 1992, 1993). The methods and criteria of estimating the cause of death were the same as those in the exploited forests. In all, 4653 carcasses were found in the exploited forests of BPF and 329 in BNP.

\section{Acorn crop}

Data on oak acorn crop in 1976-1993 were provided by the Białowieża Forest Administration. The indices of crops ( $\mathrm{kg}$ ) were the annual purchases (for replantation purposes) of acorns from local people, who gathered them in the exploited part of BPF (Table 1). The amount of acorns gathered depended mainly on seed crop, but might also have been affected by prices. We believe that acorn crop in 1989 was seriously underestimated, because very low prices (due to inflation) discouraged the collectors. Based on our own observations, we assessed the 1989 acorn crop as superabundant (cf Pucek et al. 1993). Data on oak fruiting in 1967-1969 were taken from Falińska (1971).

Table 1. Characteristics of weather conditions and acorn crop in Białowieża Primeval Forest in 1969/70, 1977/78, and 1984/85-1993/94. $\mathrm{T}_{\mathrm{d}}$ - mean daily temperature in autumn-winter ( 1 November $-31 \mathrm{March}$ ), $\mathrm{T}_{\min }$ - minimum daily temperature recorded during that period (both in ${ }^{\circ} \mathrm{C}$ ), $\mathrm{SC}$ - mean daily snow cover (1 November - $31 \mathrm{March}$ ), $\mathrm{SC}_{\max }$ - maximum snow cover recorded during that period (both in $\mathrm{mm}$ ), Acorn crop - total annual purchase of acorn (in $\mathrm{kg}$ ) by the Białowieża Forest Administration. Data on acorn crop in the following years were also used for the analysis: $1967-100 \%, 1968-17 \%$ (after Falińska 1971), $1975-4690 \mathrm{~kg}(9 \%), 1976-15253 \mathrm{~kg}(30 \%), 1982-50100 \mathrm{~kg}(100 \%)$, $1983-0 \mathrm{~kg}(0 \%) . *$ index underestimated due to very high inflation rate of currency and poor prices, actual crop was superabundant (estimated as $100 \%$, in parentheses). ? - no data.

\begin{tabular}{|c|c|c|c|c|c|c|}
\hline \multirow{2}{*}{$\begin{array}{l}\text { Winter } \\
\text { season }\end{array}$} & \multirow{2}{*}{$\mathrm{T}_{\mathrm{d}}$} & \multirow{2}{*}{$\mathrm{T}_{\min }$} & \multirow{2}{*}{$\mathrm{SC}$} & \multirow{2}{*}{$\mathrm{SC}_{\max }$} & \multicolumn{2}{|c|}{ Acorn crop } \\
\hline & & & & & $\begin{array}{c}\text { Purchase } \\
\text { (kg) }\end{array}$ & $\begin{array}{c}\% \text { of } \max \\
\text { crop }\end{array}$ \\
\hline $1969 / 70$ & -4.06 & -24.4 & 425.0 & 950 & 0 & 0 \\
\hline $1977 / 78$ & -1.21 & -15.4 & 190.2 & 590 & 0 & 0 \\
\hline $1984 / 85$ & -4.54 & -20.8 & 100.2 & 330 & $?$ & $?$ \\
\hline $1985 / 86$ & -2.66 & -22.5 & 193.7 & 570 & 736 & 1 \\
\hline $1986 / 87$ & -3.76 & -24.7 & 196.4 & 450 & 7763 & 15 \\
\hline $1987 / 88$ & -0.22 & -12.2 & 82.1 & 350 & 0 & 0 \\
\hline $1988 / 89$ & 1.22 & -13.7 & 24.0 & 210 & 2400 & 5 \\
\hline $1989 / 90$ & 2.23 & -12.4 & 19.4 & 240 & 8120 & $16^{*}(100)$ \\
\hline $1990 / 91$ & 0.02 & -17.6 & 40.9 & 250 & 0 & 0 \\
\hline $1991 / 92$ & 0.49 & -16.8 & 17.4 & 150 & 0 & 0 \\
\hline $1992 / 93$ & -0.28 & -16.1 & 46.0 & 200 & 7000 & 14 \\
\hline $1993 / 94$ & -0.87 & -17.2 & 81.6 & 230 & 7000 & 14 \\
\hline
\end{tabular}




\section{Weather conditions}

Data on weather (listed in Table 1) were obtained from the Białowieża meteorological station located in the Białowieża glade (central part of BPF) and included: mean daily temperature, mean daily snow cover (both calculated for the period 1 November - 31 March), the maximum snow cover, and the total number of days with snow cover.

\section{Results}

\section{Selectivity of various mortality factors towards species of ungulates}

During the 25 years (1969-1994), the numbers of ungulates in the exploited part of BPF varied markedly. European bison grew in numbers after successful

Table 2. Estimated population size, culling or harvest, and number of carcasses of ungulates and assessed cause of death in the exploited part of Białowieża Primeval Forest. ${ }^{a}$ numbers summed for all years listed; b calculated for 10 years (1984-1993) when wolf and lynx populations recovered after persecution; ${ }^{\mathrm{c}}$ for further calculations this number was divided proportionally into wolf kills and lynx kills classes; ${ }^{d}$ moose numbers estimated by snowtracking. Blank space denotes no data available, dashes mean no carcasses found or no harvest/culling.

\begin{tabular}{|c|c|c|c|c|c|c|c|c|c|}
\hline \multirow[b]{2}{*}{ Year } & \multirow{2}{*}{$\begin{array}{c}\text { Estimated } \\
\text { popu- } \\
\text { lation } \\
\text { size }\end{array}$} & \multirow{2}{*}{$\begin{array}{l}\text { Culling } \\
\text { or } \\
\text { harvest }\end{array}$} & \multicolumn{7}{|c|}{ Number of carcasses found with cause of death } \\
\hline & & & $\begin{array}{l}\text { Gun- } \\
\text { wo- } \\
\text { unded }\end{array}$ & $\begin{array}{l}\text { Poach- } \\
\text { ed }\end{array}$ & Wolf & Lynx & $\begin{array}{l}\text { Stray } \\
\text { dogs }\end{array}$ & $\begin{array}{c}\text { raffic } \\
\text { accid- } \\
\text { ents }\end{array}$ & $\begin{array}{l}\text { Dis- } \\
\text { ease, } \\
\text { undet. }\end{array}$ \\
\hline 1 & 2 & 3 & 4 & 5 & 6 & 7 & 8 & 9 & 10 \\
\hline \multicolumn{10}{|c|}{ Bison bonasus } \\
\hline 1969 & 180 & 1 & - & - & - & - & - & - & 5 \\
\hline 1970 & 197 & - & & & & & & & 11 \\
\hline 1972 & 236 & 7 & & & 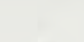 & & & & 3 \\
\hline 1977 & 218 & 19 & - & - & - & - & - & - & 6 \\
\hline 1984 & 256 & 17 & - & - & - & - & - & - & 6 \\
\hline 1985 & 243 & 16 & - & 1 & - & - & - & 1 & 9 \\
\hline 1986 & 224 & 16 & - & 2 & - & - & - & - & 9 \\
\hline 1987 & 235 & 19 & - & 2 & - & - & - & 1 & 6 \\
\hline 1988 & 228 & 25 & - & 1 & - & - & - & 1 & 6 \\
\hline 1989 & 254 & 5 & - & - & - & - & - & 1 & 1 \\
\hline 1990 & 272 & 8 & - & - & - & - & - & - & 7 \\
\hline 1991 & 271 & 22 & - & 3 & - & - & - & 1 & 4 \\
\hline 1992 & 259 & 30 & - & - & - & - & - & - & 5 \\
\hline 1993 & 251 & 31 & - & 1 & - & - & - & - & 4 \\
\hline Total $^{\mathrm{a}}$ & & 216 & 0 & 10 & 0 & 0 & 0 & 5 & 82 \\
\hline Mean $^{b}$ & & 19 & 0 & 1.0 & 0 & 0 & 0 & 0.5 & 5.7 \\
\hline SD & & 8.5 & & 1.0 & & & & 0.5 & 2.3 \\
\hline $\begin{array}{l}\text { Percent of total } \\
\text { mortality }\end{array}$ & & 72 & & 4 & & & & 2 & 22 \\
\hline $\begin{array}{l}\text { Percent of total non- } \\
\text { culling mortality }\end{array}$ & & & & 14 & & & & 7 & 79 \\
\hline
\end{tabular}


Table 2 - continued.

\begin{tabular}{|c|c|c|c|c|c|c|c|c|c|}
\hline 1 & 2 & 3 & 4 & 5 & 6 & 7 & 8 & 9 & 10 \\
\hline \multicolumn{10}{|c|}{ Alces alces } \\
\hline $1968 / 69$ & $3^{\mathrm{d}}$ & & & & & & & & \\
\hline $1969 / 70$ & $7^{\mathrm{d}}$ & - & - & - & - & - & - & - & - \\
\hline $1970 / 71$ & $12^{\mathrm{d}}$ & - & & & & & & & \\
\hline $1972 / 73$ & $21^{\mathrm{d}}$ & 2 & & & & & & & \\
\hline $1977 / 78$ & & 5 & - & - & - & - & - & - & - \\
\hline $1984 / 85$ & & 18 & - & 1 & - & - & - & - & 1 \\
\hline $1985 / 86$ & & 15 & - & 1 & - & - & - & - & - \\
\hline $1986 / 87$ & & 6 & - & - & - & - & - & - & - \\
\hline $1987 / 88$ & & 7 & - & - & 1 & - & - & - & 1 \\
\hline $1988 / 89$ & & 5 & 1 & - & - & - & - & - & 2 \\
\hline $1989 / 90$ & & 12 & 3 & 1 & - & - & - & - & - \\
\hline $1990 / 91$ & 203 & 19 & 1 & 1 & 1 & - & - & - & - \\
\hline $1991 / 92$ & 54 & 36 & 4 & 2 & 1 & - & - & - & 5 \\
\hline $1992 / 93$ & 75 & 20 & 5 & 1 & - & - & - & - & 2 \\
\hline $1993 / 94$ & & 28 & 3 & 1 & 1 & - & - & - & 2 \\
\hline Total $^{\mathrm{a}}$ & & 173 & 17 & 8 & 4 & 0 & 0 & 0 & 13 \\
\hline Mean $^{\text {b }}$ & & 17 & 1.7 & 0.8 & 0.4 & 0 & 0 & 0 & 1.3 \\
\hline SD & & 9.9 & 1.9 & 0.6 & 0.5 & & & & 1.6 \\
\hline $\begin{array}{l}\text { Percent of total non- } \\
\text { harvest mortality }\end{array}$ & & & & 32 & 16 & & & & 52 \\
\hline \multicolumn{10}{|c|}{ Cervus elaphus } \\
\hline $1968 / 69$ & 2900 & 429 & & & & & & & \\
\hline $1969 / 70$ & & 450 & - & - & - & - & - & - & 809 \\
\hline $1970 / 71$ & 1420 & 334 & & & & & & & \\
\hline $1972 / 73$ & 1435 & 228 & & & & & & & \\
\hline $1977 / 78$ & & 319 & - & - & - & - & - & - & 15 \\
\hline $1984 / 85$ & & 476 & 4 & 4 & \multicolumn{2}{|c|}{$83^{\mathrm{c}}$} & - & - & 24 \\
\hline $1985 / 86$ & & 401 & 1 & - & 37 & 2 & - & 3 & 7 \\
\hline $1986 / 87$ & & 442 & 3 & - & 43 & 3 & - & - & 13 \\
\hline $1987 / 88$ & & 368 & 4 & - & 36 & 5 & 2 & 1 & 16 \\
\hline $1988 / 89$ & & 237 & 4 & 1 & 17 & 2 & - & 4 & 13 \\
\hline $1989 / 90$ & & 231 & 10 & 6 & 19 & 2 & 1 & 3 & 4 \\
\hline $1990 / 91$ & 2741 & 469 & 19 & 10 & 26 & 3 & - & 1 & 12 \\
\hline $1991 / 92$ & 1575 & 705 & 33 & 14 & 49 & 8 & - & - & 17 \\
\hline $1992 / 93$ & 1650 & 699 & 30 & 13 & 61 & 4 & 3 & 4 & 23 \\
\hline $1993 / 94$ & & 699 & 32 & 16 & 47 & 14 & 1 & 7 & 30 \\
\hline Total $^{\mathrm{a}}$ & & 6487 & 140 & 64 & 409 & 52 & 7 & 23 & 983 \\
\hline Mean $^{b}$ & & 473 & 14.0 & 6.4 & 40.9 & 5.2 & 0.7 & 2.3 & 15.9 \\
\hline SD & & 178.7 & 13.2 & 6.4 & 18.0 & 4.0 & 1.0 & 2.3 & 7.9 \\
\hline $\begin{array}{l}\text { Percent of total non- } \\
\text { harvest mortality }^{\text {b }}\end{array}$ & & & & 9 & 58 & 7 & 1 & 3 & 22 \\
\hline
\end{tabular}


Table 2 - concluded.

\begin{tabular}{|c|c|c|c|c|c|c|c|c|c|}
\hline 1 & 2 & 3 & 4 & 5 & 6 & 7 & 8 & 9 & 10 \\
\hline \multicolumn{10}{|c|}{ Capreolus capreolus } \\
\hline $1968 / 69$ & 4170 & 493 & & & & & & & \\
\hline $1969 / 70$ & & 461 & - & - & - & - & - & - & 1226 \\
\hline $1970 / 71$ & 1120 & 174 & & & & & & & \\
\hline $1972 / 73$ & 1040 & 243 & & & & & & & \\
\hline $1977 / 78$ & & 239 & - & - & - & - & - & - & 3 \\
\hline $1984 / 85$ & & 135 & - & 2 & \multicolumn{2}{|c|}{$13^{\mathrm{c}}$} & - & - & 10 \\
\hline $1985 / 86$ & & 151 & - & 2 & 4 & 5 & - & 1 & 7 \\
\hline $1986 / 87$ & & 299 & - & - & 18 & 10 & - & 1 & 27 \\
\hline $1987 / 88$ & & 268 & - & - & 13 & 4 & - & 1 & 5 \\
\hline $1988 / 89$ & & 220 & 2 & - & 5 & 15 & 1 & 2 & 5 \\
\hline $1989 / 90$ & & 205 & 1 & 2 & 3 & 3 & - & 4 & 12 \\
\hline $1990 / 91$ & 2500 & 295 & 6 & 3 & 7 & 21 & 4 & 4 & 15 \\
\hline $1991 / 92$ & 2495 & 458 & 16 & 10 & 13 & 18 & - & 4 & 28 \\
\hline $1992 / 93$ & 1495 & 619 & 15 & 8 & 17 & 24 & 9 & 8 & 28 \\
\hline $1993 / 94$ & & 555 & 11 & 6 & 26 & 29 & 8 & 9 & 17 \\
\hline Total $^{\mathrm{a}}$ & & 4815 & 51 & 33 & 112 & 136 & 22 & 34 & 1383 \\
\hline Mean $^{\text {b }}$ & & 320 & 5.1 & 3.3 & 11.2 & 13.6 & 2.2 & 3.4 & 15.4 \\
\hline SD & & 167.8 & 6.5 & 3.5 & 7.5 & 9.2 & 3.5 & 3.1 & 9.3 \\
\hline $\begin{array}{l}\text { Percent of total non- } \\
\text { harvest mortality }\end{array}$ & & & & 7 & 23 & 28 & 4 & 7 & 31 \\
\hline \multicolumn{10}{|c|}{ Sus scrofa } \\
\hline $1968 / 69$ & 1410 & 430 & & & & & & & \\
\hline $1969 / 70$ & & 299 & - & - & - & - & - & - & 417 \\
\hline $1970 / 71$ & 610 & 263 & 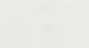 & & & & & & \\
\hline $1972 / 73$ & 1445 & 302 & & & & & & & \\
\hline $1977 / 78$ & & 467 & - & - & - & - & - & - & 68 \\
\hline $1984 / 85$ & & 405 & 2 & 1 & 4 & - & - & - & 8 \\
\hline $1985 / 86$ & & 451 & 6 & - & 4 & 1 & - & 4 & 30 \\
\hline $1986 / 87$ & & 350 & 3 & - & - & - & - & - & 34 \\
\hline $1987 / 88$ & & 583 & 1 & 2 & 4 & - & - & 1 & 36 \\
\hline $1988 / 89$ & & 283 & 15 & - & - & - & 3 & - & 19 \\
\hline $1989 / 90$ & & 150 & 2 & 3 & 1 & - & - & 1 & 9 \\
\hline $1990 / 91$ & 1780 & 1106 & 33 & 12 & - & 1 & 5 & 4 & 67 \\
\hline $1991 / 92$ & 1040 & 751 & 36 & 16 & 18 & - & 6 & 4 & 27 \\
\hline $1992 / 93$ & 1230 & 477 & 21 & 15 & 12 & - & 8 & 5 & 40 \\
\hline $1993 / 94$ & & 243 & 9 & 6 & 29 & - & 5 & - & 7 \\
\hline Total $^{\mathrm{a}}$ & & 6560 & 128 & 55 & 72 & 2 & 27 & 19 & 762 \\
\hline Mean $^{b}$ & & 480 & 12.8 & 5.5 & 7.2 & 0.2 & 2.7 & 1.9 & 27.7 \\
\hline SD & & 279.5 & 13.1 & 6.4 & 9.6 & 0.4 & 3.1 & 2.1 & 18.4 \\
\hline $\begin{array}{l}\text { Percent of total non- } \\
\text { harvest mortality }\end{array}$ & & & & 12 & 16 & $<1$ & 6 & 4 & 61 \\
\hline
\end{tabular}


reintroduction to the wild in 1952 (Table 2). Moose, after few decades of absence, recolonised the Forest from the East in 1970 (Table 2). Red deer, roe deer and wild boar were, in various proportions, steady components of the ungulate community (Table 2). Harvest of game species was small in 1969-1989/90 but in 1990/91-1993/94 had increased nearly 2 times in red deer, roe deer and wild boar and nearly 4 times in moose. The harvest increase was caused by complaints of damage to forest restocks. Bison, after reaching a level of 230 individuals, became a subject of culling to stabilize their number.

While the yearly numbers of harvested ungulates are absolute numbers (or close to such), all other figures on mortality are only samples collected on a random basis. Bison most often died from injuries, parazitic disease and various pathological factors (79\% of non-culled deaths) and poaching (14\%) (Table 2$)$. In moose, the major causes of non-harvest mortality were disease and starvation (52\%), and poaching with snares ( $32 \%$ of carcasses) (Table 2 ). In red deer, wolf predation was the most important mortality factor (58\%), followed by disease and starvation $(22 \%)$ (Table 2). Roe deer suffered most from disease and starvation $(31 \%)$, predation by lynx ( $28 \%$ ) and by wolf (23\%) (Table 2). Amongst wild boar carcasses, disease and starvation was determined as the cause of death in $61 \%$, and wolf predation in $16 \%$ (Table 2).

Proportions of ungulate species harvested or culled were set similar to those in the population (Fig. 2). The number of cases of man-caused mortality (gun-wounds, poaching, traffic accidents) showed a clear tendency to increase with time. Ungulates that were found dead from gun-wounds were more frequent in years of high harvest plans; numbers of gun-wounded ungulates correlated with the numbers of harvested animals $(r=0.821, p<0.01, n=12$ years). The species of ungulates found dead from gun-wounds were similar in composition to that of harvested/culled ungulates, except for roe deer, which was found less than expected among gun-wounded ungulates (Fig. 2). Poaching (basically with snares) by local inhabitants increased after 1989 and was not strongly biased towards any species, but somewhat higher than expected in moose (Fig. 2). Accidents (with cars and, less often, trains) grew steadily from 1969/70 till 1993/94, which reflected the obvious increase in traffic. Ungulates suffered from accidents proportionally to their abundance in the living community with a slight, but not significant, trend for roe deer to be killed more than expected (Fig. 2).

Natural mortality included predation by wolves, lynx, and death from disease and starvation. Predation by stray dogs was still human-related; experience of game wardens holds that most of the stray dogs were poachers' dogs. Wolves significantly specialised on red deer ( $68 \%$ of their ungulate prey) and took them more than expected (Fig. 2). All other species, especially wild boar, were preyed upon by wolves less than expected (Fig. 2). During the study, the estimated number of wolves in the exploited forests of the Polish part of BPF varied from 0 to 19 (Table 3). The total number of all ungulates killed by wolves and found each year grew significantly with increasing numbers of wolves $(r=0.582, p<0.05, n=12$ 


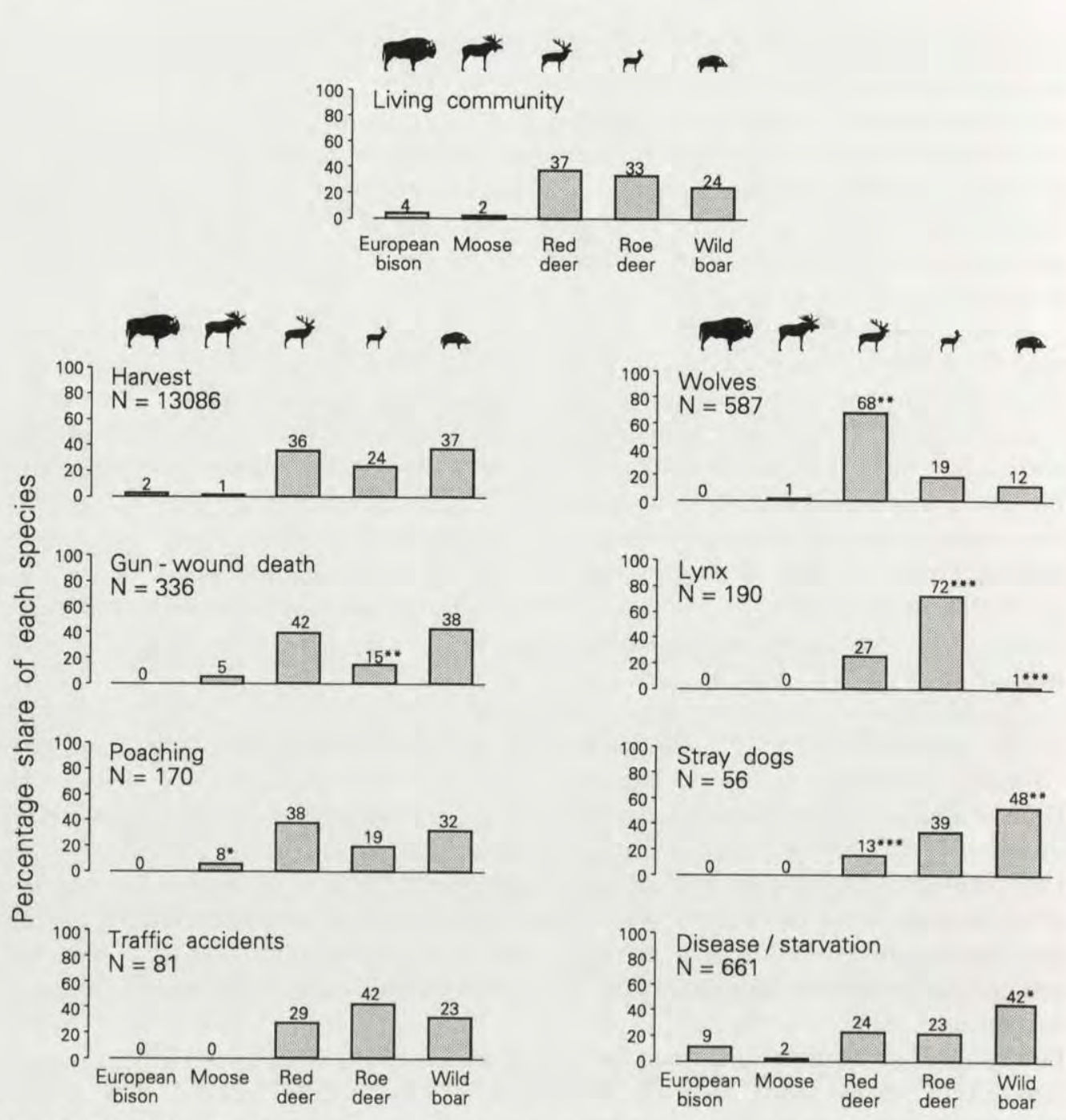

Fig. 2. Selectivity of 8 factors of mortality towards ungulate species in the exploited part of BPF (pooled data for 1984/85-1993/94), $n$ - total number of ungulates found dead from a given mortality factor or harvested by hunters (taken as $100 \%$ in each graph). Species structure of living community - data from a driving census in $1991 .{ }^{*} p<0.05,{ }^{* *} p<0.01,{ }^{* * *} p<0.001$ ( $G$-test for homogeneity of percentages, pairwise comparisons of each species' share in the living community and among all ungulates found dead from a given mortality factor).

years). The relationship was statistically significant in red deer, the preferred prey of wolves (Fig. 3). It was less pronounced in roe deer and moose, and least so in wild boar which was strongly avoided by wolves (cf Fig. 2).

In the exploited forests of BPF, lynx specialised on roe deer ( $72 \%$ of ungulate prey) and killed them significantly more than expected (Fig. 2). European bison and moose were never recorded as lynx prey, and wild boar were killed very rarely 


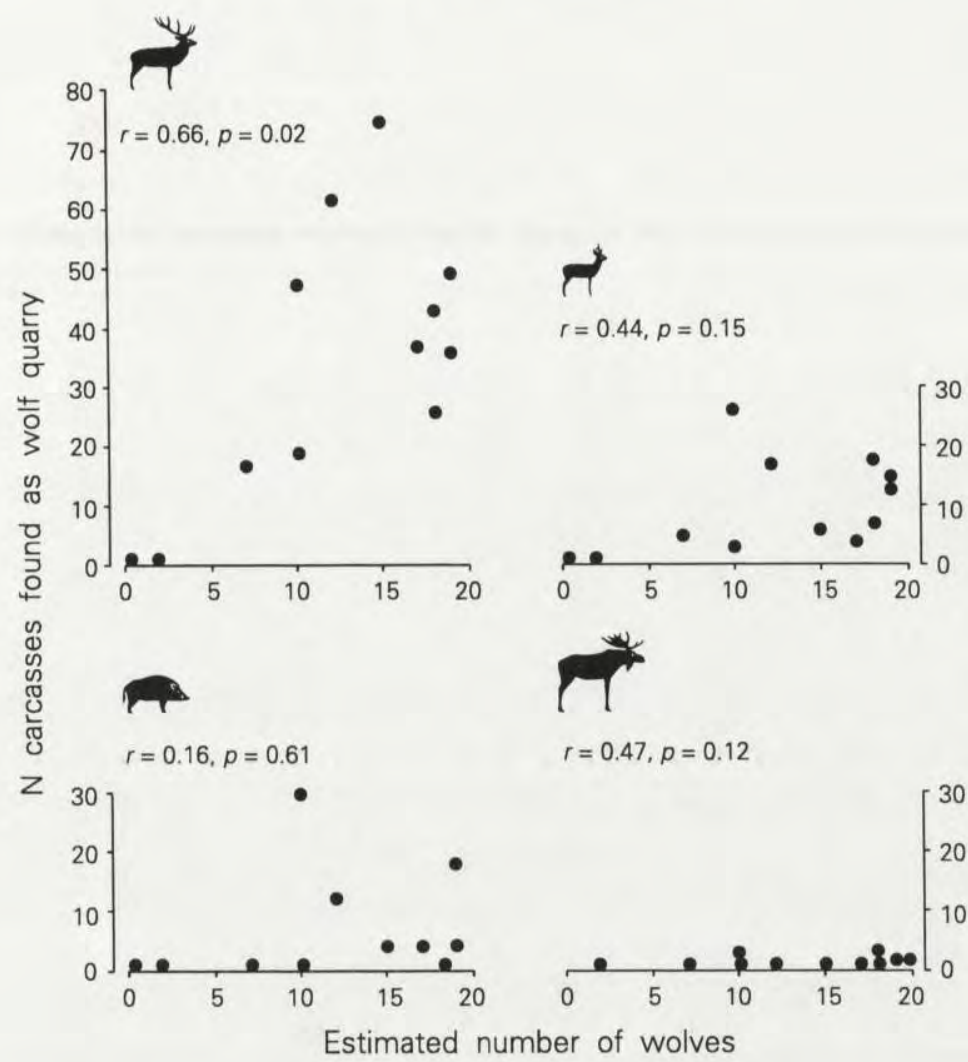

Fig. 3. Numbers of ungulates found as wolves' quarry in relation to the estimated numbers of wolves in the exploited part of BPF (data for 1969/70, 1977/78, 1984/85-1993/94; each point = one year).

Table 3. Numbers of wolves and lynx in the exploited forests of BPF (as estimated by snowtracking).

\begin{tabular}{lcc}
\hline Winter season & Number of wolves & Number of lynx \\
\hline $1969 / 70$ & 0 & 10 \\
$1977 / 78$ & 2 & 20 \\
$1984 / 85$ & 15 & 18 \\
$1985 / 86$ & 17 & 9 \\
$1986 / 87$ & 18 & 11 \\
$1987 / 88$ & 19 & 16 \\
$1988 / 89$ & 7 & 12 \\
$1989 / 90$ & 10 & 12 \\
$1990 / 91$ & 18 & 11 \\
$1991 / 92$ & 19 & 13 \\
$1992 / 93$ & 12 & 12 \\
$1993 / 94$ & 10 & 16 \\
\hline
\end{tabular}


Table 4. Estimated population size (drive census) and numbers of carcasses found with various causes of death in the pristine forests of BNP in 1986/87- -1992/93. No bison carcass and only one poached moose were found in BNP.

\begin{tabular}{|c|c|c|c|c|}
\hline \multirow{2}{*}{$\begin{array}{l}\text { Winter } \\
\text { season }\end{array}$} & \multirow{2}{*}{$\begin{array}{l}\text { Estimated } \\
\text { population } \\
\text { size }\end{array}$} & \multicolumn{3}{|c|}{ Number of carcasses found with cause of death } \\
\hline & & Poaching & $\begin{array}{c}\text { Predation } \\
\text { (wolf and lynx) }\end{array}$ & $\begin{array}{c}\text { Disease, } \\
\text { undetermined }\end{array}$ \\
\hline \multicolumn{5}{|c|}{ Cervus elaphus } \\
\hline $1986 / 87$ & & 1 & 22 & 1 \\
\hline $1987 / 88$ & & 3 & 10 & - \\
\hline $1988 / 89$ & & 2 & 13 & - \\
\hline $1989 / 90$ & & 1 & 2 & - \\
\hline $1990 / 91$ & 540 & 3 & 17 & 1 \\
\hline $1991 / 92$ & 670 & 8 & 8 & 2 \\
\hline $1992 / 93$ & & - & 12 & 7 \\
\hline Total & & 18 & 84 & 11 \\
\hline Mean & & 2.6 & 12.0 & 1.6 \\
\hline SD & & 2.6 & 6.4 & 2.5 \\
\hline $\begin{array}{l}\text { Percent of total } \\
\text { mortality }\end{array}$ & & 16 & 74 & 10 \\
\hline \multicolumn{5}{|c|}{ Capreolus capreolus } \\
\hline $1986 / 87$ & & - & 1 & - \\
\hline $1987 / 88$ & & - & - & - \\
\hline $1988 / 89$ & & 1 & 3 & - \\
\hline $1989 / 90$ & & 1 & - & - \\
\hline $1990 / 91$ & 176 & - & 1 & - \\
\hline $1991 / 92$ & 128 & 1 & 4 & - \\
\hline 1992/93 & & 1 & - & - \\
\hline Total & & 4 & 9 & 0 \\
\hline Mean & & 0.6 & 1.3 & 0 \\
\hline $\mathrm{SD}$ & & 0.5 & 1.6 & \\
\hline $\begin{array}{l}\text { Percent of total } \\
\text { mortality }\end{array}$ & & 31 & 69 & 0 \\
\hline \multicolumn{5}{|c|}{ Sus scrofa } \\
\hline $1986 / 87$ & & 1 & 1 & 26 \\
\hline $1987 / 88$ & & 3 & 4 & 21 \\
\hline $1988 / 89$ & & 1 & 1 & 3 \\
\hline $1989 / 90$ & & 1 & 3 & 1 \\
\hline $1990 / 91$ & 850 & 3 & 1 & 110 \\
\hline $1991 / 92$ & 280 & 6 & 5 & 9 \\
\hline 1992/93 & & - & 3 & - \\
\hline Total & & 15 & 18 & 170 \\
\hline Mean & & 2.1 & 2.6 & 24.3 \\
\hline SD & & 2.0 & 1.6 & 39.1 \\
\hline $\begin{array}{l}\text { Percent of total } \\
\text { mortality }\end{array}$ & & 7 & 9 & 84 \\
\hline
\end{tabular}


(Fig. 2). Estimated numbers of lynx varied from 9 to 20 individuals during the study years (Table 3), and there was no direct relationship between numbers of lynx and number of lynx prey found. Stray dogs were able to seize red deer, roe deer, and wild boar. They killed wild boar significantly more and red deer less than expected from their proportions in community (Fig. 2).

Death from starvation, cold and disease depended on the severity of winters. Snow cover during the winters of $1977 / 78$ and 1984/85-1993/94 was within the normal range of variation for the area, but the winter of 1969/70 was catastrophically snowy and cold (see Fig. 1). Snow cover over $70 \mathrm{~cm}$ persisted for about 2 months. During that winter, nearly $30 \%$ of ungulate populations (except for bison) was found dead (Table 2) and, obviously, many carcasses were not recorded, because large parts of the Forest were not accessible. The proportions of ungulates found dead in winter 1969/70 were nearly the same as those in the community as censused in 1968/69 (in parentheses): European bison 2\% (1\% in the community), red deer $33 \%(34 \%)$, roe deer $50 \%(48 \%)$, and wild boar $17 \%(16 \%)$. During the other 11 winters, wild boar were more sensitive to disease/starvation and were found dead more frequently than expected from their share in the community (Fig. 2).

In the pristine forests of BNP, ungulates were not hunted but were poached, mainly with snares. Mortality of various species due to poaching was the same as their proportion in the community (Table 4, Fig. 4). In BNP, red deer and wild boar strongly dominated, whereas roe deer were rare. Thus, both species of large predators (the wolf and the lynx) fed predominantly on red deer (Jędrzejewski $e t$ al. 1992, 1993, Jędrzejewska et al. 1994). In BNP, wild boar sufferred from
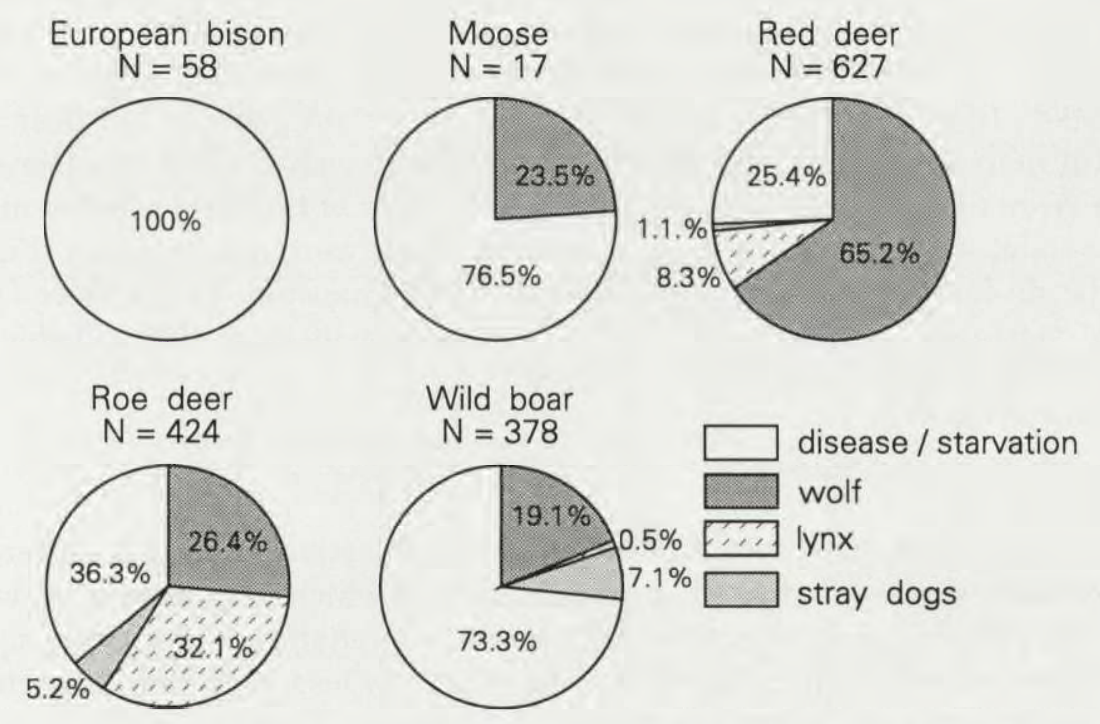

Fig. 4. Selectivity of four factors of mortality towards ungulate species in the pristine forests of BNP (pooled data for 1986/87-1992/93). Species structure of living community - data from drive censuses in 1991 and 1992 averaged. Explanations as in Fig. 2. 

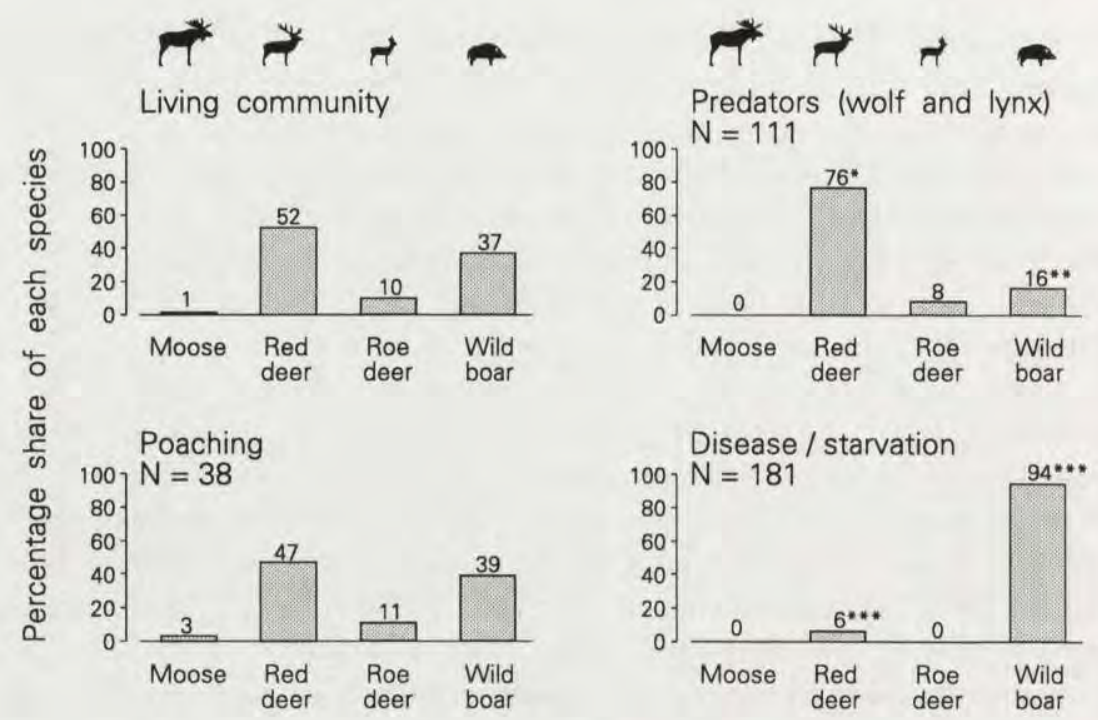

Fig. 5. Role of predation and non-predatory factors (disease in bison and disease/starvation in other ungulates) in the total natural (ie not caused by man) mortality of ungulates in 1984/85-1993/94 in the exploited forests of BPF, $n$-total number of carcasses found.

predation less than expected, but it significantly outnumbered other species among ungulates that had died from disease and starvation (Fig. 4).

Relative roles of predation and disease/starvation in the total natural mortality of the five species of ungulates in the exploited forests of BPF were compared during the 10 years (1984/85-1993/94), when both species of native predators occurred in BPF. Predation played the most important roles in red deer $(75 \%$ of the total mortality from natural causes, mainly by wolves) and roe deer ( $64 \%$ of mortality, mainly by lynx) (Fig. 5). Only one-quarter of the total natural mortality of moose and wild boar was due to predation; bison were not predated (Fig. 5). In the pristine forests of BNP, predation was most important in roe deer $(100 \%$ of natural mortality), red deer $(88 \%)$, and least so in wild boar (10\%) (Table 4$)$.

\section{Sex and age selectivity of various mortality factors}

Generally, most mortality factors acted nonselectively towards different sex and age classes of red and roe deer populations, of which most data were collected (Table 5). The strongest selection was shown by predators and poachers. Wolves and lynx preyed on adult male red deer significantly less often than expected from their proportion in the living population. Lynx strongly preferred red deer calves, and stray dogs seized roe deer fawns more often than at random (Table 5). Out of 4 moose killed by wolves, 3 were calves. Both hunting harvest and the total 
Table 5. Sex and age class selectivity of various mortality factors towards red deer, roe deer and moose compared with the structure of the living population (data for 1984/85-1993/94). Data on age and sex structure of the populations of red and roe deer (estimated visually during a drive census in 1991) are taken as representative for the whole 10-year period. In moose, the age/sex structure of population varied during the studied decade, so two estimates are given (drive censuses in 1991 and 1993).* $p<$ 0.05 , ** $p<0.01$, $^{* *} p<0.001$ (pairwise $G$-test for homogeneity of percentages, used to test the differences of a given mortality factor and living population).

\begin{tabular}{|c|c|c|c|c|c|c|c|}
\hline \multirow{2}{*}{ Cause of death } & \multicolumn{2}{|c|}{ Juv $<1$ yr } & \multicolumn{2}{|c|}{ Ad females } & \multicolumn{2}{|c|}{ Ad males } & \multirow{2}{*}{ Total $n$} \\
\hline & $n$ & $\%$ & $n$ & $\%$ & $n$ & $\%$ & \\
\hline \multicolumn{8}{|c|}{ Cervus elaphus } \\
\hline Living population & 80 & 27 & 137 & 46 & 80 & 27 & 297 \\
\hline Hunting harvest & 1401 & 29 & 2185 & 45 & 1273 & 26 & 4859 \\
\hline Total non-harvest mortality & 267 & 35 & 343 & 44 & 161 & 21 & 771 \\
\hline Gun-wounds & 32 & 23 & 76 & 54 & 32 & 23 & 140 \\
\hline Poaching & 11 & 17 & 23 & 36 & 30 & $47^{*}$ & 64 \\
\hline Accidents & 9 & 39 & 10 & 44 & 4 & 17 & 23 \\
\hline Stray dogs & 5 & - & 2 & - & 0 & - & 7 \\
\hline Wolves & 123 & 37 & 165 & 49 & 47 & $14^{*}$ & 335 \\
\hline Lynx & 29 & $67^{* * *}$ & 14 & 33 & 0 & $0^{* * *}$ & 43 \\
\hline Disease, starvation & 58 & 37 & 53 & 33 & 48 & 30 & 159 \\
\hline \multicolumn{8}{|c|}{ Capreolus capreolus } \\
\hline Living population & 78 & 29 & 124 & 46 & 67 & 25 & 269 \\
\hline Hunting harvest & 782 & 26 & 1218 & 40 & 1011 & 34 & 3011 \\
\hline Total non-harvest mortality & 168 & 32 & 277 & 52 & 84 & 16 & 529 \\
\hline Gun-wounds & 19 & 37 & 20 & 39 & 12 & 24 & 51 \\
\hline Poaching & 7 & 21 & 22 & $67^{*}$ & 4 & $12^{*}$ & 33 \\
\hline Accidents & 8 & 24 & 16 & 47 & 10 & 29 & 34 \\
\hline Stray dogs & 11 & $50^{*}$ & 8 & 36 & 3 & 14 & 22 \\
\hline Wolves & 22 & 21 & 68 & 64 & 16 & 15 & 106 \\
\hline Lynx & 32 & 25 & 75 & 58 & 22 & 17 & 129 \\
\hline Disease, starvation & 69 & 45 & 68 & 44 & 17 & $11^{*}$ & 154 \\
\hline \multicolumn{8}{|c|}{ Alces alces } \\
\hline Living population '91 & 26 & 32 & 34 & 43 & 20 & 25 & 80 \\
\hline '93 & 10 & 20 & 25 & 50 & 15 & 30 & 50 \\
\hline Hunting harvest & 30 & 18 & 82 & 49 & 54 & 33 & 166 \\
\hline Total non-harvest mortality & 7 & 17 & 20 & 50 & 13 & 33 & 40 \\
\hline Gun-wounds & 1 & - & 8 & - & 8 & - & 17 \\
\hline Poaching & 0 & - & 6 & - & 1 & - & 7 \\
\hline Wolves & 3 & - & 1 & - & 0 & - & 4 \\
\hline Disease, starvation & 3 & - & 5 & - & 4 & - & 12 \\
\hline
\end{tabular}

non-harvest mortality took random culls from sex/age classes of red deer, roe deer and moose, although slightly higher than expected cull of young was recorded in both species of deer (Table 5). 
During the studied decade, the population of European bison included, on average, $27 \%$ adult males ( $>4 \mathrm{yr}$ ), $38 \%$ adult females ( $>4 \mathrm{yr}$ ), $20 \%$ subadults of both sexes $(2-3 \mathrm{yr})$, and $15 \%$ calves $(<1 \mathrm{yr})$. Among culled European bison, 27\% were adult males, $23 \%$ adult females, $27 \%$ subadults, and $23 \%$ were calves. In the total non-culling mortality, adult males prevailed ( $42 \%)$, followed by adult females $(25 \%)$, calves $(21 \%)$ and subadults $(12 \%)$.

\section{The roles of snow cover and acorn crop in ungulate mortality}

Numbers of carcasses of ungulates that died from starvation and disease varied between years. Regression analysis was conducted to find how much variation in that mortality could be explained by variable snow depth and acorn crop. Analysis was conducted separately for the samples from the exploited forests of BPF (5 species of ungulates) and the pristine forests of BNP (wild boar only, because the samples of red deer and roe deer carcasses were too small). Moreover, for exploited forests, the whole series of 12 years (including the extremely severe winter of 1969/70) and the 11-year series with only moderate and mild winters were analysed separately. Then, if more than one dependent variable was involved, the semipartial correlation squared $\left(s r^{2}\right)$ was calculated; $s r^{2}$ expresses the unique contribution of the independent variable as a proportion of total variance of the dependent variable (Tabachnick and Fidell 1983).

In wild boar, mortality from starvation/disease was influenced mainly by snow cover (Snow) and acorn crop of the previous year $\left(\mathrm{Oak}_{n-1}\right)$. Increase in the values of both variables caused increase in the number of wild boar carcasses found. In the whole series of data from the exploited forests of BPF $(\mathrm{Y}=-37.32+0.85$ Snow $+0.57 \mathrm{Oak}_{n-1}, R^{2}=0.783, p=0.002$ ), snow cover was the most important factor $\left(s r^{2} i=0.764\right.$ for snow cover and $s r^{2} i=0.020$ for acorn crop in year $\left.n-1\right)$. In the series without the extremely heavy winter $1969 / 70(\mathrm{Y}=13.457+0.122$ Snow + $0.504 \mathrm{Oak}_{n-1}, R^{2}=0.595, p=0.042$ ), acorn crop was a decisive factor of variation of wild boar mortality from disease and starvation $\left(s r^{2} i=0.482\right.$ for acorn crop in year $n-1$, and $s r^{2} i=0.130$ for snow cover). In the pristine forests of BNP, acorn crop of the previous year played the essential role in wild boar mortality $(\mathrm{Y}=$ $-1.650+1.057 \mathrm{Oak}_{n-1}+0.126$ Snow $, R^{2}=0.985, p<0.0005 ; s r^{2} i=0.999$ for acorn crop and $s r^{2}{ }_{i}=0.043$ for snow cover).

In red deer, roe deer, European bison and moose, variation in acorn crop had no relationship with deaths from starvation and disease. Variation in snow cover did not affect ungulate mortality in mild and moderate winters, either. Only in the long (12-year) series with the extremely heavy winter (1969/70) included, did the numbers of carcasses correlate positively with snow cover (red deer: $\mathrm{Y}=$ $-107.074+1.576$ Snow, $R^{2}=0.663, p=0.001$; roe deer: $\mathrm{Y}=-168.427+2.404$ Snow, $R^{2}=0.662, p=0.001$. 


\section{Discussion}

The presented material does not allow us to calculate absolute measures of ungulate mortality. Also, methodological problems involved in estimating the population size of ungulates means that reliable data on ungulate numbers are available for European bison only, whereas for others, reliable information from 6 years scattered over the 25 year period (1969-1994) was obtained in the exploited forests and on 2 years in the National Park. Except for harvest quotas, which are absolute numbers, all other measures of mortality are only samples. Nonetheless, the data allow us to reconstruct some mechanisms of the functioning of ungulate populations and to define the most important factors originally affecting their numbers in the deciduous forest zone in lowland Europe.

Wild boar was affected mainly by depth of snow and acorn crop, its favourite food resource. Wild boar deaths from starvation and disease grew proportionally with the increase in acorn crop of the previous year. The biological mechanism of this correlation is that heavy acorn crop causes an increase in the numbers of wild boar, many of which die in the following year.

Oak produces heavy seed crops at 6 to 9 year intervals (Pucek et al. 1993). In recent decades, mast years occurred in 1949-50, 1958, 1967, 1977, 1982 and 1989. One or two years after each mast are usually characterized by a nil crop, and all other years by crops up to $20 \%$ of the maximum crop. The amount of acorns produced by mature forests with oak in Białowieża are on average $300 \mathrm{~kg} / \mathrm{ha}$ in intermediate years and up to $2000 \mathrm{~kg} / \mathrm{ha}$ in mast year (review and sources in Pucek et al. 1993). After the fall of mast, wild boar changed their spatial distribution towards concentrating in mature oak-lime-hornbeam forests. In such years, Lebedeva (1956) working in the Belarussian part of BPF found $34 \%$ of wild boar observations in oak-lime-hornbeam forests that covered $<10 \%$ of the entire forest area. After the fall of mast, wild boar intensely forage on acorn, survive winter well, and next spring, they breed early and intensively. Both the share of breeding females in boar population and the mean number of piglets per mother increases (Lebedeva 1956). However, already in autumn of the year following the mast, the mortality of piglets is very high, and by November-February, the mean number of piglets per mother is the same as in non-mast years (Lebedeva 1956). Moreover, the nil acorn crop that follows the mast year causes very high mortality of both adults and young boar. Groot Bruinderink et al. (1994) found a similar dependence of wild boar demography and condition on acorn crop in Holland.

In the mature pristine forests of BNP in June 1990 (after the mast in autumn 1989), wild boar reached the density of 43 animals $/ \mathrm{km}^{2}$ (Jędrzejewska et al. 1994). Until February 1992, boar density in BNP dropped to 6 boar $/ \mathrm{km}^{2}$ (Jędrzejewska et al. 1994).

Mast years are stimulated by weather conditions and are synchronised over the entire range of European temperate deciduous forests in Europe (review in Pucek et al. 1993). Therefore, the changes in wild boar population dynamics 
originally must have been synchronised in the whole range of forests with oak. Currently, such forests survive only in small patches in the devastated landscape of Europe, so they play very little role in shaping the population dynamics of wild boar.

Snow cover, if deep enough, and frozen soil make it difficult for wild boar to root and get food. During the periods with deep snow cover, boars starve, are victims of disease and die on mass. Severe winters also occur synchronously over large parts of Europe. For instance, in 1955/56 deaths of wild boar and other ungulates were reported from Germany, Poland and Russia (Caboń 1958, Braunschweig 1957, Kazenevsky 1961), and in 1967/68 from Caucasus Mts, Georgia (Kotov 1969).

Even as far south as Iran (Mohammad Reza Shah National Park), snow cover and seed crop of oak Quercus casanaefolia were two crucial factors shaping the reproduction and survival of wild boar (de Vos and Sassani 1977). Also, in the temperate deciduous forests of the Amur territory (Far East of Russia), wild boar survival in winter depends on snow cover and acorn crop (Rakov 1970).

Predation was far less important for wild boar population than food resources (acorn crop) and weather. Wild boar's body structure, active defense behaviour and large groups maintained year round (Jędrzejewski et al. 1992) make it a difficult and even dangerous prey for wolves and lynx. In the Palaearctic (data from 5 localities with large predators present), predation contributed on average $25 \%$ to the total natural mortality of wild boar (see review in Jędrzejewski et al. 1993). Predation on wild boar may be significantly higher in these places, where boar coexists with Siberian tiger Panthera tigris, which is the only large carnivore in Palaearctic that predominantly preys on wild boar (Rakov 1970). In Europe, however, wild boar does not have any natural predator specialising on it.

In BPF, stray dogs specialised on wild boar what may be the result of the very old local poaching habits. Big dogs are trained to capture wild boar. The scale of their impact is unknown, but since stray dogs are shot by game wardens whenever seen in the forest, their influence on ungulates is certainly by order of magnitude smaller than that of wild predators.

Generally, in the pristine forests of BNP, wild boar population dynamics has been shaped by natural conditions (food resources and winter weather). In the exploited forests of BPF, natural factors have been more and more replaced by various human impacts. In the $1960 \mathrm{~s}-1980 \mathrm{~s}$, when hunting harvest was about $20 \%$ of the population, natural factors still could have been important. In the $1990 \mathrm{~s}$, harvest quotas increased and led to a decline of wild boar numbers. Moreover, the exploitation of old growth forests and replacing them with young plantations (mostly coniferous) greatly changed the habitat for wild boar and led to lower densities of boar in these secondary forests (Jędrzejewska et al. 1994).

Red deer prefers deciduous browse (Dzięciołowski 1970), but during the mast years it feeds on acorns intensively. In BPF, the most important factors affecting the natural mortality of red deer were wolves and also snow. Predation seems to 
be the most important factor of red deer mortality in the Palaearctic. Data from 7 localities where red deer coexists with predators (review in Jędrzejewski et al. 1993) show that, on average, $80 \%$ of the natural mortality of red deer was caused by predation (mainly wolves). Therefore, wolves seem to be a strong limiting factor of red deer numbers, and reduction or extermination of wolves could lead to an increase of red deer numbers. Medium snow depths did not directly cause red deer mortality, although they did increase deer susceptibility to wolf predation (Jędrzejewski et al. 1992). It was only very deep snow that caused catastrophic mortality of red deer from starvation and inanition. As mentioned above, such catastrophic winters occur synchronously over vast areas in Europe.

During the last decades in the exploited forests of BPF, red deer were probably never functioning naturally. Its main enemy, the wolf, was severely persecuted or restricted in numbers. Forestry practices (clearcutting of old growth and large scale replantating mostly with conifers such as Scots pine and Norway spruce) has deteriorated the old growth forest habitat for red deer, and - inevitably provoked its browsing in replantations, which offer high supply of browse (Dzięciołowski and Borowski 1980). In the 1990s, complaints from foresters led to a drastic reduction of red deer by hunters. Also, poaching has been seriously affecting the deer.

In the pristine forests of BNP, red deer population is shaped mostly by natural factors. However, BNP $\left(47 \mathrm{~km}^{2}\right)$ is too small to fully support a single family of wolves (cf Goszczyński 1986). In the past, persecution of wolves in the exploited forests obviously affected the wolf-deer relationships in the National Park, too. Also, poachers infiltrate BNP and kill deer. Poaching (mainly with snares) by local inhabitants serves as supply of meat for households. It rapidly increased after 1989 , when the free market reforms in Poland triggered high rate of unemployment and decline in living standards. Also, the process of transformations caused an administrative chaos that is always conductive to illegal use of forest resources.

In BPF, roe deer suffered mostly from predation by lynxes and wolves. This is typical throughout its entire range in the Palaearctic. The review of studies done in 5 localities, where roe deer coexisted with predators, showed that, on average, $85 \%$ of the natural mortality of roe deer was due to predation, predominantly by lynx (Jędrzejewski et al. 1993). Snow cover did not affect roe deer, unless extremely deep. In the exploited forests of BPF, roe deer were lightly harvested, especially after the mass mortality in 1969/70. High numbers of lynx in the 1970s (W. Jędrzejewski et al. unpubl. data) could have been a limiting factor for roe deer recovery. In the $1990 \mathrm{~s}$, the roe deer harvest increased substantially and caused further decline in numbers.

Expansion of moose from the East to the Polish part of BPF began in the late 1960s, not halted by the small harvest. Since 1992, a heavier harvest has led to a rapid decline in moose numbers. In BPF, only $24 \%$ of natural mortality of moose was caused by predation. Data from 8 localities in Palaearctic (Jędrzejewski et al. 
1993) showed that, on average, $59 \%$ of moose mortality was due to predation by large carnivores.

In BPF, European bison does not have any natural predators now. In the 19th century, when red deer were temporarily extinct from BPF, bison were preyed upon by wolves and brown bears Ursus arctos Linnaeus, 1758 (Kartsov 1903). However, native bears were exterminated from BPF before 1880 (Kartsov 1903). At present, as in other restored populations of European bison in eastern Europe, wolves only rarely hunt on them (eg in the Caucasian Game Reserve; Filonov 1989).

In BPF, abundant fodder (hay) for bison is provided in several feeding racks every winter (Krasiński 1967, 1978). In effect, bison do not suffer from malnutrition in winter, their natural mortality is low (3\%) and culling is necessary to keep the population numbers stable.

Acknowledgements: We thank the following game wardens for recording the carcasses of dead ungulates in the exploited forests of BPF: J. Bołbot, P. Buszko, B. Dawidziuk, A. Rejent, W. Stolc, T. Werkowski, J. Wiśniewski, H. Witak, P. Wołkowycki and W. Wołkowycki. The technician staff of MRI (especially E. Bujko, M. Szlachciuk, K. Zub) and Earthwatch Research Corps helped in recording the carcasses in the Białowieża National Park. K. Zub prepared the figures. The work was supported by the Mammal Research Institute PAS budget, and partly by Earthwatch and KBN 444169102 grants.

\section{References}

Braunschweig A. 1957. Rehverluste im Winter 1955/56. Zeitschrift für Jagdwissenschaft 3: 69-79.

Caboń K. 1958. Das Massensterben von Wildschweinen im Naturstaatspark von Białowieża im Winter 1955/56. Acta Theriologica 2: 71-82.

Dzięciołowski R. 1970. Food of the red deer as determined by rumen content analyses. Acta Theriologica 15: 89-110.

Dzięciołowski R. and Borowski S. 1980. Browse supply in lowland forests of Eastern Poland. Holarctic Ecology 3: 203-213.

Falińska K. 1971. An estimate of diaspore production in the ecosystem of a mixed oak-hornbeam forest (Querco-Carpinetum) in the Białowieża National Park. Ekologia polska 19: 525-561.

Faliński J. B. 1986. Vegetation dynamics in temperate lowland primeval forest. Dr W. Junk Publishers, Dordrecht: 1-537.

Filonov K. P. 1989. Ungulates and large predators in wildlife reserves. Nauka, Moskva: 1-251. [In Russian]

Goszczyński J. 1986. Locomotor activity of terrestrial predators and its consequences. Acta Theriologica 31: 79-95.

Groot Bruinderink G. W. T. A., Hazebroek E. and Voet H. van den. 1994. Diet and condition of wild boar, Sus scrofa scrofa, without supplementary feeding. Journal of Zoology, London 233: 631-648.

Jędrzejewska B., Okarma H., Jędrzejewski W. and Miłkowski L. 1994. Effects of exploitation and protection on forest structure, ungulate density and wolf predation in Białowieża Primeval Forest, Poland. Journal of Applied Ecology 31: 664-676.

Jędrzejewski W., Jędrzejewska B., Okarma, H. and Ruprecht A. L. 1992. Wolf predation and snow cover as mortality factors in the ungulate community of the Białowieża National Park, Poland. Oecologia (Berl.) 90: 27-36.

Jędrzejewski W., Schmidt K., Miłkowski L., Jędrzejewska B. and Okarma H. 1993. Foraging by lynx and its role in ungulate mortality: the local (Białowieża Forest) and the Palaearctic viewpoints. Acta Theriologica 38: 385-403. 
Kartsov G. 1903. [Belovezha Primeval Forest. Its historical description, contemporary game management, and monarchial hunts in the Forest]. A. Marks, St. Petersburg: 1-409. [In Russian]

Kazenevsky P. F. 1961. On more case of death in the wild ungulates (winters 1955/56). Byulleten Moskovskogo Obshchestva Ispytatelei Prirody, Otdelenie Biologii 66(6): 147-148. [In Russian]

Kotov V. A. 1969. A hard winter for wild ungulate animals in the Caucasian Preserve. Byulleten Moskovskogo Obshchestva Ispytatelei Prirody, Otdelenie Biologii 74(1): 57-61. [In Russian with English summary]

Krasiński Z. 1967. Free living European bisons. Acta Theriologica 12: 391-405.

Krasiński Z. A. 1978. Dynamics and structure of the European bison population in the Białowieża Primeval Forest. Acta Theriologica 23: 3-48.

Lebedeva L. S. 1956. [Ecological characteristics of the wild boar in Belovezha Primeval Forest]. Uchenye Zapiski Moskovskogo Gorodskogo Pedagogicheskogo Instituta im. V. P. Potemkina 61: 105-271. [In Russian]

Olszewski J. L. 1986. The role of forest ecosystems in modyfying local climate of the Białowieża Primeval Forest, as revealed by air temperature characteristics. Prace habilitacyjne, Ossolineum, Wrocław: 1-222. [In Polish with English summary]

Pucek Z., Bobek B., Łabudzki L., Miłkowski L., Morow K. and Tomek A. 1975. Estimates of density and number of ungulates. Polish ecological Studies 1(2): 121-135.

Pucek Z., Jędrzejewski W., Jędrzejewska B. and Pucek M. 1993. Rodent population dynamics in a primeval deciduous forest (Białowieża National Park) in relation to weather, seed crop, and predation. Acta Theriologica 38: 199-232.

Rakov N. V. 1970. Causes of mortality of the wild boar and its interrelation with predators in the Amur territory. Zoologicheskiï Zhurnal 49: 1220-1228. [In Russian with English summary]

Tabachnick B. G. and Fidell L. S. 1983. Using multivariate statistics. Harper \& Row, Publishers, New York: 1-509.

Vos A. de and Sassani A. 1977. Eine Studie der Population des Schwarzwildes (Sus scrofa) in dem Mohammad Reza Shah Nationalpark. Zeitschrift für Jagdwissenschaft 23: 113-126.

Received 25 January 1995, accepted 5 May 1995. 